\title{
Spreadsheet-Based Simulation Models for Decision Support: Case of Strategic Pairings in Sport Tournaments with Match Play for Team Competition
}

\author{
James K. HO \\ Information \& Decision Sciences, College of Business Administration \\ University of Illinois at Chicago \\ Chicago, IL 60607, USA \\ e-mail:jimho@uic.edu
}

Received: October 2011; accepted: January 2012

\begin{abstract}
In sport tournaments where teams compete in match play format, the pairing of players in matches is critical to the final outcomes. This paper presents simulation models using only commonplace spreadsheet software to analyze and compare strategies in such pairings based on actual or estimated performance of individual players. The approach can be a useful decision support tool for captains and coaches of competing teams in collegiate conferences, club leagues, or international sport tournaments.
\end{abstract}

Keywords: spreadsheet-based decision support, simulation models; sport tournament, match play, team competition, pairing strategy.

\section{Introduction}

The sports industry, with global revenue projected at US \$120 billion in 2011 (Clark, 2010), is a hotbed for decision analysis, from high-level strategic planning, event-specific project management (Ragsdale et al., 2008), to field-level coaching. The application of operations research methodology and decision support tools has been studied for over a half century (Wright, 2009). In this article, we focus on spreadsheet-based simulation models for decision support as illustrated in case of international golf competition.

The two prevalent forms of competition in golf are stroke play and match play. In stroke play, a player's total score in a match counts. The player with the lowest score wins the match. In match play, opponents compete to win individual holes, and the player (or team of players) who wins the most holes wins the match. Match play with two individuals, competing one on one, is known as singles match play. This format, in the setting of a single-elimination tournament, is used, for example, in the U.S. Amateur Championship. When teams of two players are matched, many variations of match play are possible. The two most common ones are known as four-ball and foursomes. In fourball, each player plays his or her own ball throughout the round. On each hole, the lower 
score of the two players on one side serves as that side's score. Hence the format is also called better ball. In foursomes, each side plays only one ball, with the two players taking alternate shots. Hence the format is also called alternate shot.

Typical team competition at all levels, from club leagues, collegial conferences, to major international events such as the Ryder Cup ${ }^{1}$, the Presidents Cup ${ }^{2}$, and the Solheim $\mathrm{Cup}^{3}$, comprise a combination of matches in all three of the above match play formats. For example, the biennial Ryder Cup competition currently pits two teams of twelve, representing the U.S. and Europe respectively, in eight foursomes matches, eight fourball matches, and twelve singles matches over four days. The biennial Presidents Cup competition also pits two teams of twelve, representing the U.S. and non-European rest of the world respectively, in eleven foursomes matches, eleven four-ball matches, and twelve singles matches over four days. The team captains are responsible for pairing the players in the doubles matches, as well as selecting the order of play in the singles matches. For the Ryder Cup, the lists submitted by the captains are matched "doubleblind" and the resulting pairings cannot be changed unless a player is sick or injured. For the Presidents Cup, the captains get to hand-match the games interactively, allowing for dynamic and intriguing strategies in adjusting the player match-ups. Jack Nicklaus, the legendary golfer who captained the Ryder Cup twice and the Presidents Cup four times for the U.S. reflected on the significance of match-play pairing strategies (Nicklaus, 2004):

Team play is fascinating on two distinct levels. The captain is charged with formulating two-man teams in the foursomes (alternate-shot) and four-ball (best-ball) competitions, and sending out players in just the right order in the singles matches. The challenge is an art as much as a science, and the captain relies on intuition, input from the team and observation of his players.

This paper aims to extend the "science" in support of pairing strategies in match-play competition with simulation models that can be used to analyze, project, and compare alternative scenarios. In Section 2, actual results from the 2007 Presidents Cup are used to illustrate the underlying concepts of the models, as well as the significance of their output. The methodology of the process is presented in Section 3, focusing primarily on the case of singles matches. Extensions and generalisations to doubles matches are outlined in Section 4. An up-to-date application of post-game analysis for the 2011 Solheim Cup is summarized in Section 5. An example of pre-game analysis with comparison of predicted and actual results for the 2011 Presidents Cup is reported in Section 6. Recommendations of application and future directions are discussed in Section 7. Competing teams and their captains have obvious interests in improving the odds of their teams winning. Broadcast media and their sponsors also have tremendous stakes in how close and

\footnotetext{
${ }^{1}$ The Ryder Cup, formally inaugurated in 1927, was originally a biennial competition between professional golfers representing the U.S. and Great Britain. From 1973, the British side was expanded to include Ireland, and again from 1979 to include all of Europe.

${ }^{2}$ The Presidents Cup is a biennial competition since 1994 between top professional golfers representing the U.S. and the world's best non-European players. It is played in non-Ryder Cup years.

${ }^{3}$ The Solheim Cup is contested every two years since 1990, matching teams of top U.S.-born players from the Ladies Professional Golf Association (LPGA) and top European-born players from the Ladies European Tours (LET).
} 
exciting the competition should turn out. In this regard, our methodology can contribute to both the management and marketing of such sporting events.

\section{The 2007 Presidents Cup}

This seventh meeting of the biennial competition was held at the Royal Montreal Golf Club in Montreal, Canada on 24-30 September, 2007. The U.S. Team was captained by Jack Nicklaus, and the International Team by Gary Player. Ten members of the U.S. Team were selected based on earnings from the 2005 World Golf Championships through the 2007 PGA Championship. Similarly, ten members of the International Team were chosen on the basis of the Official World Golf Ranking through the 2007 PGA Championship (excluding players eligible for the European Ryder Cup Team). The two captains each made two Captain's Picks to round out their 12-man teams. In the 22 doubles matches, one point was awarded for a win, and half point for a tie. In case of ties after 18 holes in the 12 singles matches, extra holes would be played to break ties, unless the tournament had already been clinched by one team. Each team needed 17.5 points to win the cup.

After all the doubles matches on the first three days, the U.S. Team held a commanding lead of 14.5 to 7.5 , and needed to win only 3 out of the 12 matches on the final day to claim victory. While it was still mathematically possible for the International Team to come back by winning ten of the singles matches, the lopsided situation did little to set the final Sunday up as a spectacular sporting event on television. As it turned out, the International Team managed to keep the audience engaged by winning seven of the matches. Their valiant efforts and performance was highlighted by Canada's local favourite Mike Weir edging out No. 1 world-ranked Tiger Woods, 1 up at the final hole. The U.S. Team won with a final score of 19.5 to 14.5 .

Given the performance of the players, could the International Team have done even better with alternative pairings? Could the U.S. Team have won with an even wider margin? To answer these questions, we first compiled a complete, hole-by-hole performance database for all 24 players, starting with the twelve singles matches played on the final Sunday (PGA Tour, 2007). For holes won or lost by concession, the number of strokes was inferred. For matches that were decided in less than 18 holes, the players' best scores from four-ball matches played on Friday or Saturday were used as estimates to complete the data. Remaining missing gaps were approximated by team scores in foursome matches, and as a last resort by an assumption of par in three cases. The data for the 24 players are shown in Table 1.

With the pairing giving by the respective ordering of players on the two teams, a spreadsheet model was constructed to track the hole-by-hole progress of the twelve singles matches. The results are shown in Table 2 with positive scores in favour of the U.S. Team. For example, in Match 26, Tiger Woods was 3 down against Mike Weir after ten holes, recovering to all-square after 17 , but losing 1 down at the last. The last unshaded cell for each match gives the final result. With the actual pairings, the total scores in the singles matches were 7 to 5 in favour of the International Team. To simplify the model for the exploratory purposes at hand, a half point was scored for each team in the event 
Table 1

Actual and estimated scores in 2007 Presidents Cup singles matches

\begin{tabular}{|c|c|c|c|c|c|c|c|c|c|c|c|c|c|c|c|c|c|c|c|}
\hline$\overline{\text { HOLE }}$ & 1 & 2 & 3 & 4 & 5 & 6 & 7 & 8 & 9 & 10 & 11 & 12 & 13 & 14 & 15 & 16 & 17 & 18 & \\
\hline PAR & 4 & 4 & 4 & 4 & 3 & 5 & 3 & 4 & 4 & 4 & 4 & 5 & 3 & 4 & 4 & 4 & 3 & 4 & 70 \\
\hline \multicolumn{20}{|l|}{ USA } \\
\hline \multicolumn{20}{|l|}{ Total points $=5$} \\
\hline Scott Verplank & $* 3$ & 4 & 4 & 5 & 4 & 5 & 3 & 4 & 5 & 4 & 4 & 4 & 3 & 4 & 4 & 3 & 2 & $4^{a}$ & 69 \\
\hline Lucas Glover & 4 & 3 & 3 & 4 & 3 & 4 & 3 & 4 & 4 & 4 & 4 & 4 & 3 & 4 & 3 & 5 & 3 & $\underline{5}$ & 67 \\
\hline Phil Mickelson & 5 & 3 & 4 & 4 & 3 & 5 & $* 3$ & 4 & 4 & 3 & 4 & 4 & 3 & 4 & $4^{f}$ & $4^{f}$ & $3^{f}$ & $4^{f}$ & 68 \\
\hline Tiger Woods & 4 & 4 & 4 & 5 & 3 & $\underline{6}$ & 2 & 4 & 4 & 4 & 3 & 4 & 3 & 4 & $* 4$ & 4 & 3 & 5 & 70 \\
\hline Woody Austin & 4 & 3 & 5 & 4 & 3 & 4 & 3 & 3 & 5 & 4 & 3 & 4 & 3 & 4 & 4 & 3 & 3 & 3 & 65 \\
\hline Zach Johnson & 4 & 3 & 4 & 5 & 3 & 5 & 2 & 4 & 4 & 3 & 4 & 5 & 3 & 4 & 3 & 4 & 3 & $4 t$ & 67 \\
\hline David Toms & 5 & 4 & 4 & 4 & 3 & 5 & 3 & 4 & 4 & 4 & 4 & 4 & 3 & 3 & 4 & 4 & 3 & 4 & 69 \\
\hline Stewart Cink & 3 & 3 & 3 & 3 & 2 & 5 & 3 & 3 & 4 & 4 & 5 & 4 & 3 & $* 4$ & $4^{f}$ & $4^{f}$ & $4^{f}$ & $4^{f}$ & 65 \\
\hline Steve Stricker & 4 & 4 & 4 & 4 & 3 & 4 & 3 & 4 & 4 & 5 & 4 & 5 & 2 & $* 4$ & 4 & 4 & 3 & $\underline{5}$ & 70 \\
\hline Hunter Mahan & 4 & 6 & 4 & 4 & 3 & 5 & 3 & 4 & 3 & 4 & 4 & 4 & 3 & 4 & 5 & 5 & $2^{f}$ & $4^{f}$ & 71 \\
\hline Charles Howell III & 4 & 3 & 4 & 5 & 3 & 5 & 3 & 3 & 5 & 5 & 3 & 4 & 2 & 3 & 3 & 5 & 2 & $4^{a}$ & 66 \\
\hline Jim Furyk & 4 & 2 & 4 & 4 & 3 & 5 & 3 & 5 & 4 & 4 & 4 & 5 & 3 & 5 & 4 & 3 & 3 & $4^{s}$ & 69 \\
\hline \multicolumn{20}{|l|}{\begin{tabular}{|l|} 
International \\
\end{tabular}} \\
\hline \multicolumn{20}{|l|}{ Total points $=7$} \\
\hline Rory Sabbatini & $\underline{4}$ & 3 & 5 & 4 & 3 & 5 & 3 & 4 & 4 & 5 & 4 & 5 & 3 & 4 & 4 & 4 & 3 & 3 & 70 \\
\hline Ernie Els & 4 & 3 & 4 & 5 & 3 & 6 & 2 & 3 & 4 & 4 & 4 & 4 & 2 & 3 & 4 & 4 & 3 & $* 4$ & 66 \\
\hline Vijay Singh & 4 & 4 & 5 & 4 & 3 & 6 & $\underline{4}$ & 4 & 4 & 4 & 4 & 5 & 3 & 4 & $3^{t}$ & $4^{s}$ & $3^{t}$ & $4^{s}$ & 72 \\
\hline Mike Weir & 4 & 3 & 4 & 4 & 3 & $* 5$ & 2 & 4 & 4 & 4 & 4 & 5 & 3 & 5 & $\underline{5}$ & 4 & 2 & 3 & 68 \\
\hline Angel Cabrera & 4 & 3 & 4 & 4 & 3 & 5 & 2 & 4 & 4 & 3 & 4 & 4 & 3 & 4 & 3 & 4 & 2 & $3^{f}$ & 63 \\
\hline Adam Scott & 3 & 4 & 4 & 5 & 2 & 4 & 2 & 4 & 4 & 4 & 5 & 4 & 3 & 3 & 5 & 4 & 2 & $4^{a}$ & 66 \\
\hline Trevor Immelman & 5 & 4 & 4 & 4 & 3 & 4 & 3 & 5 & 5 & 4 & 4 & 5 & 3 & 4 & 3 & 3 & 3 & 5 & 71 \\
\hline Nick O’Hern & 3 & 4 & 4 & 4 & 3 & 4 & 4 & 4 & 3 & 3 & 5 & 5 & 4 & $\underline{5}$ & $4^{f}$ & $4^{f}$ & $4^{f}$ & $4^{f}$ & 70 \\
\hline Geoff Ogilvy & 4 & 3 & 4 & 4 & 3 & 5 & 3 & 3 & 4 & 4 & 4 & 6 & 3 & $\underline{5}$ & 4 & 3 & 3 & $* 4$ & 69 \\
\hline K.J. Choi & 4 & 4 & 4 & 5 & 4 & 4 & 3 & 4 & 4 & 3 & 4 & 4 & 3 & 3 & 4 & 4 & $4^{s}$ & $4^{s}$ & 68 \\
\hline Stuart Appleby & 4 & 4 & 4 & 4 & 4 & 5 & 2 & 4 & 4 & $* 4$ & 4 & 5 & 3 & 3 & 5 & 4 & 2 & $4^{s}$ & 70 \\
\hline Retief Goosen & 4 & 3 & 4 & 5 & 2 & 5 & 2 & 3 & 3 & 4 & 4 & 5 & 4 & 3 & 4 & 5 & 2 & $4^{s}$ & 67 \\
\hline \multicolumn{20}{|l|}{ Sunday Singles } \\
\hline \multicolumn{20}{|l|}{$f=$ Friday Four-Ball } \\
\hline \multicolumn{20}{|l|}{$s=$ Saturday Four-Ball } \\
\hline \multicolumn{20}{|l|}{$t=$ Thursday Foursomes } \\
\hline \multicolumn{20}{|l|}{$a=$ Assumed par } \\
\hline *Won by concession, & 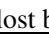 & & 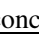 & 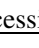 & & & & & & & & & & & & & & & \\
\hline
\end{tabular}

of a tie after 18 holes, rather than extending the match to a sudden-death playoff. This omission can be easily removed in further work with the knowledge of which holes will be used in a playoff.

To facilitate the tracking of total team score, a logical model linked to the detailed scores was constructed and shown in Table 3. Here, "C" indicates continuation of the 
Table 2

Hole-by-hole scoring in the singles matches

\begin{tabular}{lrrrrrrrrrrrrrrrrrrl}
\hline HOLE & 1 & 2 & 3 & 4 & 5 & 6 & 7 & 8 & 9 & 10 & 11 & 12 & 13 & 14 & 15 & 16 & 17 & 18 & Won by \\
\hline MATCH 23 & 1 & 0 & 1 & 0 & -1 & -1 & -1 & -1 & -2 & -1 & -1 & 0 & 0 & 0 & 0 & 1 & 2 & 1 & USA \\
MATCH 24 & 0 & 0 & 1 & 2 & 2 & 3 & 2 & 1 & 1 & 1 & 1 & 1 & 0 & -1 & 0 & -1 & -1 & -2 & INT'L \\
MATCH 25 & -1 & 0 & 1 & 1 & 1 & 2 & 3 & 3 & 3 & 4 & 4 & 5 & 5 & 5 & 4 & 4 & 4 & 4 & USA \\
MATCH 26 & 0 & -1 & -1 & -2 & -2 & -3 & -3 & -3 & -3 & -3 & -2 & -1 & -1 & 0 & 1 & 1 & 0 & -1 & INT'L \\
MATCH 27 & 0 & 0 & -1 & -1 & -1 & 0 & -1 & 0 & -1 & -2 & -1 & -1 & -1 & -1 & -2 & -1 & -2 & -2 & INT'L \\
MATCH 28 & -1 & 0 & 0 & 0 & -1 & -2 & -2 & -2 & -2 & -1 & 0 & -1 & -1 & -2 & -1 & -1 & -2 & -2 & INT'L \\
MATCH 29 & 0 & 0 & 0 & 0 & 0 & -1 & -1 & 0 & 1 & 1 & 1 & 2 & 2 & 3 & 2 & 1 & 1 & 2 & USA \\
MATCH 30 & 0 & 1 & 2 & 3 & 4 & 3 & 4 & 5 & 4 & 3 & 3 & 4 & 5 & 6 & 6 & 6 & 5 & 5 & USA \\
MATCH 31 & 0 & -1 & -1 & -1 & -1 & 0 & 0 & -1 & -1 & -2 & -2 & -1 & 0 & 1 & 1 & 0 & 0 & -1 & INT'L \\
MATCH 32 & 0 & -1 & -1 & 0 & 1 & 0 & 0 & 0 & 1 & 0 & 0 & 0 & 0 & -1 & -2 & -3 & -2 & -2 & INT'L \\
MATCH 33 & 0 & 1 & 1 & 0 & 1 & 1 & 0 & 1 & 0 & -1 & 0 & 1 & 2 & 2 & 3 & 2 & 2 & 3 & USA \\
MATCH 34 & 0 & 1 & 1 & 2 & 1 & 1 & 0 & -1 & -2 & -2 & -2 & -2 & -1 & -2 & -2 & -1 & -2 & -1 & INT'L \\
\hline
\end{tabular}

Table 3

Logical model for team score in the singles matches

\begin{tabular}{|c|c|c|c|c|c|c|c|c|c|c|c|c|c|c|c|c|c|c|}
\hline HOLE & 1 & 2 & 3 & 4 & 5 & 6 & 7 & 8 & 9 & 10 & 11 & 12 & 13 & 14 & 15 & 16 & 17 & 18 \\
\hline ATCH23 & $\mathrm{C}$ & $\mathrm{C}$ & $\mathrm{C}$ & C & C & $\mathrm{C}$ & $\mathrm{C}$ & $\mathrm{C}$ & $\mathrm{C}$ & $C$ & $\mathrm{C}$ & C & C & $\mathrm{C}$ & $\mathrm{C}$ & $\mathrm{C}$ & 1 & \\
\hline МАТCH24 & $\mathrm{C}$ & $\mathrm{C}$ & $\mathrm{C}$ & $\mathrm{C}$ & $\mathrm{C}$ & $\mathrm{C}$ & $\mathrm{C}$ & C & C & $\mathrm{C}$ & $\mathrm{C}$ & $\mathrm{C}$ & $\mathrm{C}$ & $\mathrm{C}$ & $\mathrm{C}$ & $\mathrm{C}$ & $\mathrm{C}$ & $\mathbf{0}$ \\
\hline МATCH25 & $\mathrm{C}$ & $\mathrm{C}$ & $\mathrm{C}$ & $\mathrm{C}$ & $\mathrm{C}$ & $\mathrm{C}$ & $\mathrm{C}$ & $\mathrm{C}$ & $\mathrm{C}$ & $\mathrm{C}$ & $\mathrm{C}$ & $\mathrm{C}$ & $\mathrm{C}$ & & & & & \\
\hline МАТСН26 & $\mathrm{C}$ & $\mathrm{C}$ & $\mathrm{C}$ & $\mathrm{C}$ & $\mathrm{C}$ & $\mathrm{C}$ & $\mathrm{C}$ & $\mathrm{C}$ & $\mathrm{C}$ & $\mathrm{C}$ & $\mathrm{C}$ & $\mathrm{C}$ & $\mathrm{C}$ & $\mathrm{C}$ & $\mathrm{C}$ & $\mathrm{C}$ & $\mathrm{C}$ & $\mathbf{0}$ \\
\hline МАТСН27 & $\mathrm{C}$ & $\mathrm{C}$ & $\mathrm{C}$ & C & $\mathrm{C}$ & $\mathrm{C}$ & $\mathrm{C}$ & $\mathrm{C}$ & $\mathrm{C}$ & $\mathrm{C}$ & $\mathrm{C}$ & $\mathrm{C}$ & $\mathrm{C}$ & $\mathrm{C}$ & $\mathrm{C}$ & $\mathrm{C}$ & $\mathbf{0}$ & \\
\hline MATCH28 & $\mathrm{C}$ & $\mathrm{C}$ & $\mathrm{C}$ & C & $\mathrm{C}$ & $\mathrm{C}$ & $\mathrm{C}$ & $\mathrm{C}$ & $\mathrm{C}$ & $\mathrm{C}$ & $\mathrm{C}$ & $\mathrm{C}$ & $\mathrm{C}$ & $\mathrm{C}$ & $\mathrm{C}$ & $\mathrm{C}$ & $\mathbf{0}$ & \\
\hline МАТСН 29 & $\mathrm{C}$ & $\mathrm{C}$ & $\mathrm{C}$ & $\mathrm{C}$ & $\mathrm{C}$ & $\mathrm{C}$ & $\mathrm{C}$ & 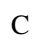 & 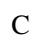 & $\mathrm{C}$ & $\mathrm{C}$ & $\mathrm{C}$ & $\mathrm{C}$ & $\mathrm{C}$ & $\mathrm{C}$ & $\mathrm{C}$ & $\mathrm{C}$ & 1 \\
\hline МАТСН30 & $\mathrm{C}$ & $\mathrm{C}$ & $\mathrm{C}$ & C & C & $\mathrm{C}$ & $\mathrm{C}$ & $\mathrm{C}$ & $\mathrm{C}$ & $\mathrm{C}$ & $\mathrm{C}$ & $\mathrm{C}$ & $\mathrm{C}$ & & & & & \\
\hline МАТCH31 & $\mathrm{C}$ & $\mathrm{C}$ & $\mathrm{C}$ & C & $\mathrm{C}$ & $\mathrm{C}$ & $\mathrm{C}$ & $\mathrm{C}$ & $\mathrm{C}$ & $\mathrm{C}$ & $\mathrm{C}$ & $\mathrm{C}$ & $\mathrm{C}$ & $\mathrm{C}$ & $\mathrm{C}$ & $\mathrm{C}$ & $\mathrm{C}$ & 0 \\
\hline MATCH32 & $\mathrm{C}$ & $\mathrm{C}$ & $\mathrm{C}$ & C & $\mathrm{C}$ & $\mathrm{C}$ & $\mathrm{C}$ & $\mathrm{C}$ & $\mathrm{C}$ & $\mathrm{C}$ & $\mathrm{C}$ & $\mathrm{C}$ & $\mathrm{C}$ & $\mathrm{C}$ & $\mathrm{C}$ & $\mathbf{0}$ & & \\
\hline IATCH33 & $\mathrm{C}$ & $\mathrm{C}$ & $\mathrm{C}$ & c & C & $\mathrm{C}$ & $\mathrm{C}$ & $\mathrm{C}$ & $\mathrm{C}$ & $\mathrm{C}$ & $\mathrm{C}$ & $\mathrm{C}$ & $\mathrm{C}$ & $\mathrm{C}$ & $\mathrm{C}$ & $\mathrm{C}$ & 1 & \\
\hline МАТСН34 & $\mathrm{C}$ & $\mathrm{C}$ & $\mathrm{C}$ & $\mathrm{C}$ & C & C & $\mathrm{C}$ & $C$ & $\mathrm{C}$ & $\mathrm{C}$ & $\mathrm{C}$ & $\mathrm{C}$ & $\mathrm{C}$ & $\mathrm{C}$ & $\mathrm{C}$ & $\mathrm{C}$ & $\mathbf{0}$ & \\
\hline
\end{tabular}

match, "1" a win for the U.S. Team, and "0" a win for the International Team. Holes not played after a match has been decided are left blank. With this logical model, a simple summation of the numerical entries returns the total score for the U.S. Team.

\section{Simulation Model Based on Actual Performance}

By rearranging the ordering of the players, the results for any alternative pairings can be generated by the above spreadsheet models. What is the expected outcome if pairings were matched randomly? Being combinatorial, the number of all possible pairings, in- 
cluding the particular ordering of the matches, is astronomical (229442532802560000 to be exact). Even assuming the U.S. Team will fix its ordering as shown in Table 1, there are still $12 !=479001600$ possible pairings for the International Team. To investigate the expected outcome of random pairings, we propose a simulation model that examines a random sample of pairings to estimate the expected outcome. This is implemented as a spreadsheet macro program (see, e.g., Şeref et al., 2007) which generates the random samples of ordering for the International Team. Each sample is matched with the fixed ordering of the U.S. Team, and the results from the logical model are tabulated. Confidence Interval estimates for the expected (average) outcome are then computed. The sample size $(N)$ is a user controlled parameter.

For example, setting $N=1000$, and with the International players numbered from 1 to 12 as ordered in Table 1, the outputs of a simulation are shown in Tables 4 and 5. We note that assuming the players would perform as they actually did, regardless of the pairing and order of play (Guryan et al., 2009), then the expected score for the International Team is 5.28 , with a $95 \%$ confidence interval of $[5.23,5.33]$. The sample size is sufficiently large to assume normality of the sample mean distribution. The highest score observed in the random sample is 7.5 , so the team had already chanced upon a very favourable pairing resulting in the actual score of 7 . While this does not preclude the existence of even more favourable pairings, it is highly unlikely that the winning score of 10 can be attained. In any case, with the combination of so many uncertain factors, not the least of which being that neither captain can pick a particular pairing unilaterally, preoccupation with the search of so-called optimal pairings will be ill-advised. The simulation approach, which takes uncertainty into account, can serve better in the strategic analysis of alternatives.

For the U.S. Team, the expected score from the simulation is 6.72 with a $95 \%$ confidence interval of $[6.67,6.77]$. This means that there must be ample alternative pairings with better results than the actual one with a score of 5 . Had the team not enjoyed the luxury of such a commanding lead coming into the last day, an extra 2 or 3 points might have made the difference between winning and losing.

Table 4

Sampling random ordering of the International Team

\begin{tabular}{|c|c|c|c|c|c|c|c|c|c|c|c|c|c|c|}
\hline \multicolumn{13}{|l|}{ Sample } & \multirow{2}{*}{$\frac{\text { U.S. }}{7}$} & \multirow{2}{*}{$\frac{\text { International }}{5}$} \\
\hline 1 & 5 & 10 & 6 & 11 & 8 & 4 & 2 & 9 & 3 & 12 & 1 & 7 & & \\
\hline 2 & 9 & 12 & 4 & 2 & 10 & 11 & 7 & 6 & 8 & 1 & 3 & 5 & 7.5 & 4.5 \\
\hline 3 & 12 & 5 & 3 & 8 & 1 & 10 & 7 & 9 & 2 & 11 & 6 & 4 & 5.5 & 6.5 \\
\hline 4 & 7 & 6 & 11 & 4 & 10 & 3 & 12 & 2 & 9 & 5 & 1 & 8 & 6 & 6 \\
\hline- & - & - & - & - & - & - & - & - & - & - & - & - & - & - \\
\hline- & - & - & - & - & - & - & - & - & - & - & - & - & - & - \\
\hline 999 & 1 & 9 & 4 & 3 & 2 & 7 & 5 & 12 & 11 & 6 & 10 & 8 & 8 & 4 \\
\hline 1000 & 5 & 1 & 4 & 2 & 7 & 3 & 8 & 9 & 6 & 10 & 12 & 11 & 7.5 & 4.5 \\
\hline
\end{tabular}


Table 5

Example of simulation results

\begin{tabular}{lll}
\hline$N=1000$ & U.S. & International \\
\hline MEAN & 6.72 & 5.28 \\
STDEV & 0.81 & 0.87 \\
$95 \%$ C.I. & {$\left[\begin{array}{lll}6.67 & 6.77\end{array}\right]$} & {$\left[\begin{array}{ll}5.23 & 5.33\end{array}\right]$} \\
MIN & 4.5 & 3.87 \\
MAX & 9 & 7.55 \\
\hline
\end{tabular}

Our model is introduced to illustrate the simulation approach. Being based on eventual scores, it is at best hind-sight and cannot be used for pre-game planning and strategic analysis as yet. In the next section, it is extended to work with estimated performance data.

\section{Simulation Model Based on Estimated Performance}

Having illustrated the use of simulation in comparative analysis of pairing strategies in match-play team competition, we now introduce a model based on estimated rather than actual performance of the players. For each player, a hole-by-hole estimate of performance is compiled in the form of a discrete probability distribution function (PDF). For each hole, the probability of the player needing any of the possible number of strokes is established. The procedure to arrive at such data can be a combination of self analysis by the player, projection by captains and coaches, input from caddies with specific knowledge of the course, as well as actual performance up to the time of analysis (Dorsel and Rotunda, 2001; Fried et al., 2004; Ketzscher and Ringrose, 2002; McHale and Forrest, 2005). Technically, we assume it is the product of appropriate focus groups. Table 6 displays the performance PDFs for two hypothetical players X and Y. For example, for the par 4 hole 1, Player $X$ has a $5 \%$ chance for a double bogie $(+2), 10 \%$ chance for a bogie $(+1), 70 \%$ chance for a par $(0), 15 \%$ chance for a birdie $(-1)$. The expected score for Player X on this particular par 70 course is 68.44 .

Table 7 shows the outcome of one random sample of a match between Player $\mathrm{X}$ and Player Y, including hole-by-hole scoring, relative scores, and the logical status of the match. Specifically, Player X fell behind after two holes, recovered after 6 holes, led through hole 13, and finally lost 1 down at the last hole. By incorporating this additional layer of uncertainty using estimated performance probabilities, we can extend the initial model for analyzing pairing strategies in the singles matches. As in the previous scenario, random samples of pairings are generated. In each case, random outcomes for each player at each hole are simulated according to the performance PDFs. The resulting team scores are tabulated and expected values computed.

Extension to doubles match-play is quite straight forward in the case of four-balls. In any simulated scenario, the better score between the two players on a team at each 
Table 6

Performance estimates for two hypothetical players

\begin{tabular}{|c|c|c|c|c|c|c|c|c|c|c|c|c|c|c|c|c|c|c|c|}
\hline HOLE & 1 & 2 & 3 & 4 & 5 & 6 & 7 & 8 & 9 & 10 & 11 & 12 & 13 & 14 & 15 & 16 & 17 & 18 & Total \\
\hline PAR & 4 & 4 & 4 & 4 & 3 & 5 & 3 & 4 & 4 & 4 & 4 & 5 & 3 & 4 & 4 & 4 & 3 & 4 & 70 \\
\hline \multicolumn{20}{|c|}{ PLAYER X } \\
\hline-3 & 0 & 0 & 0 & 0 & 0 & 0 & 0 & 0 & 0 & 0 & 0 & 0 & 0 & 0 & 0 & 0 & 0 & 0 & \\
\hline-2 & 0 & 0 & 0 & 0 & 0 & 0.02 & 0 & 0 & 0 & 0 & 0 & 0 & 0 & 0 & 0 & 0 & 0 & 0 & \\
\hline-1 & 0.15 & 0.2 & 0.25 & 0.1 & 0.2 & 0.25 & 0.2 & 0.15 & 0.2 & 0.25 & 0.1 & 0.2 & 0.2 & 0.25 & 0.2 & 0.25 & 0.2 & 0.15 & \\
\hline 0 & 0.7 & 0.75 & 0.7 & 0.7 & 0.7 & 0.7 & 0.7 & 0.7 & 0.75 & 0.7 & 0.7 & 0.7 & 0.7 & 0.7 & 0.75 & 0.7 & 0.7 & 0.7 & \\
\hline 1 & 0.1 & 0.05 & 0.05 & 0.15 & 0.1 & 0.03 & 0.1 & 0.1 & 0.05 & 0.05 & 0.15 & 0.1 & 0.1 & 0.05 & 0.05 & 0.05 & 0.1 & 0.1 & \\
\hline 2 & 0.05 & 0 & 0 & 0.05 & 0 & 0 & 0 & 0.05 & 0 & 0 & 0.05 & 0 & 0 & 0 & 0 & 0 & 0 & 0.05 & \\
\hline 3 & 0 & 0 & 0 & 0 & 0 & 0 & 0 & 0 & 0 & 0 & 0 & 0 & 0 & 0 & 0 & 0 & 0 & 0 & \\
\hline Mean & 4.05 & 3.85 & 3.8 & 4.15 & 2.9 & 4.74 & 2.9 & 4.05 & 3.85 & 3.8 & 4.15 & 4.9 & 2.9 & 3.8 & 3.85 & 3.8 & 2.9 & 4.05 & 68.44 \\
\hline
\end{tabular}

PLAYER Y

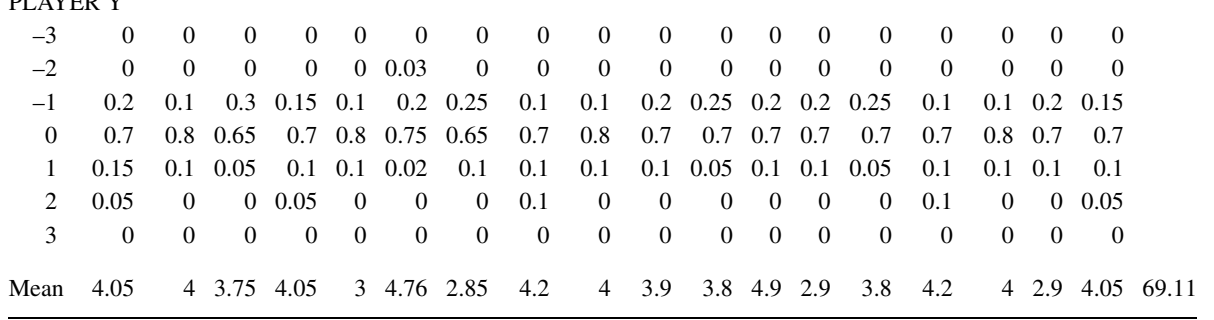

Table 7

Results of a simulated match between the two hypothetical players

\begin{tabular}{lrrrrrrrrrrrrrrrrrrr}
\hline HOLE & 1 & 2 & 3 & 4 & 5 & 6 & 7 & 8 & 9 & 10 & 11 & 12 & 13 & 14 & 15 & 16 & 17 & 18 & Total \\
PAR & 4 & 4 & 4 & 4 & 3 & 5 & 3 & 4 & 4 & 4 & 4 & 5 & 3 & 4 & 4 & 4 & 3 & 4 & 70 \\
\hline SCORE X & 4 & 5 & 4 & 4 & 3 & 5 & 2 & 5 & 4 & 5 & 3 & 6 & 3 & 4 & 4 & 4 & 3 & 4 & 72 \\
SCORE Y & 4 & 4 & 4 & 5 & 3 & 5 & 3 & 5 & 4 & 5 & 4 & 5 & 3 & 3 & 4 & 4 & 3 & 3 & 71 \\
MATCH & $\mathrm{X}$ & vs & $\mathrm{Y}$ & & & & & & & & & & & & & & & & \\
Score & 0 & -1 & -1 & 0 & 0 & 0 & 1 & 1 & 1 & 1 & 2 & 1 & 1 & 0 & 0 & 0 & 0 & -1 \\
Status & $\mathrm{C}$ & $\mathrm{C}$ & $\mathrm{C}$ & $\mathrm{C}$ & $\mathrm{C}$ & $\mathrm{C}$ & $\mathrm{C}$ & $\mathrm{C}$ & $\mathrm{C}$ & $\mathrm{C}$ & $\mathrm{C}$ & $\mathrm{C}$ & $\mathrm{C}$ & $\mathrm{C}$ & $\mathrm{C}$ & $\mathrm{C}$ & $\mathrm{C}$ & 0
\end{tabular}

hole can be extracted and compared with the corresponding outcome for the opposing team in the match. An example with the above two hypothetical Player X and Player $\mathrm{Y}$ being teamed together in four-ball match play is shown in Table 8. Their better-ball scores can then be matched with those on an opposing team as in previous simulations.

The case of foursomes is more complex. Since alternate shots are taken by the two players on a team, it is necessary to estimate their shot-by-shot performance for each hole. As an approximation, one pragmatic approach is to consider the combined performance characteristics of the two players, and establish a single estimate for the team. The team performance estimates can then be used in place of single players. 
Table 8

A simulated round with the two hypothetical players on a team in four-ball match play

\begin{tabular}{lrrrrrrrrrrrrrrrrrrr}
\hline HOLE & 1 & 2 & 3 & 4 & 5 & 6 & 7 & 8 & 9 & 10 & 11 & 12 & 13 & 14 & 15 & 16 & 17 & 18 & Total \\
PAR & 4 & 4 & 4 & 4 & 3 & 5 & 3 & 4 & 4 & 4 & 4 & 5 & 3 & 4 & 4 & 4 & 3 & 4 & 70 \\
\hline SCORE X & 4 & 5 & 4 & 4 & 3 & 5 & 2 & 5 & 4 & 5 & 3 & 6 & 3 & 4 & 4 & 4 & 3 & 4 & 72 \\
SCORE Y & 4 & 4 & 4 & 5 & 3 & 5 & 3 & 5 & 4 & 5 & 4 & 5 & 3 & 3 & 4 & 4 & 3 & 3 & 71 \\
Four-ball & $\mathrm{X}$ & $\&$ & $\mathrm{Y}$ & & & & & & & & & & & & & & & & \\
Score & 4 & 4 & 4 & 4 & 3 & 5 & 2 & 5 & 4 & 5 & 3 & 5 & 3 & 3 & 4 & 4 & 3 & 3 & 68 \\
\hline
\end{tabular}

One major difficulty that can be anticipated for the simulation of either singles or doubles match-play is an asymmetry in information. With cooperative effort on the part of players, captain and coaches, it is reasonable to expect useful estimates of performance for both individuals and pairs of players on the team. However, the availability and quality of similar information on the opposing team may be an obstacle in the simulation analysis. In this regard, the simplicity and ease of use of spreadsheet models can at least provide ample opportunities for contingency planning with quick answers to an infinitude of what-if questions.

\section{The 2011 Solheim Cup}

At this writing, the 2011 Solheim Cup has just been contested between USA and Europe and provided a timely opportunity to update our empirical studies. The biennial competition has been dominated by USA in recent years, with decisive wins in 2005, 2007, and 2009. With the prospect of USA again being the favourites in 2011, there was question within the industry regarding the continuing viability of the event as a globally televised spectacle in sports. Fortunately, Team EU delivered excellent performance during the first two days, and played to an even score of 8 to 8 entering the final day of singles matches. Then an unpleasant surprise might have tipped the scale: Christie Kerr, one of the topranked US players had to forfeit due to injury. EU ended up winning the singles matches 7 to 5 , and the Cup with a total score of 15 to 13 providing close matches that kept audiences worldwide enthralled along the way. An obvious question among sports analysts is whether Kerr's forfeiture was indeed the critical factor. We show that our simulation model can shed some light. Table 9 summarizes the actual and estimated (in cases of unfinished holes) individual performance in the singles matches. Note that since Christie Kerr did not play on Sunday, all scores for her are estimated from previous days. We first simulated using 1000 replications the expected outcome over random pairings with Kerr defaulting. It is 6.83 to 5.07 in favour of USA. The maximum attainable is 10 for USA, and 7.5 for EU. The minimum is 4.5 for USA and 2 for EU. In other words, USA had the advantage even without one of their top players. The actual outcome of 7 for EU and 5 for USA means that the Europeans had indeed achieved closed to optimal pairing 
Table 9

Actual and estimated scores in 2011 Solheim Cup singles matches

\begin{tabular}{llllllllllllllllllll}
\hline HOLE & 1 & 2 & 3 & 4 & 5 & 6 & 7 & 8 & 9 & 10 & 11 & 12 & 13 & 14 & 15 & 16 & 17 & 18 & \\
PAR & 4 & 5 & 4 & 4 & 4 & 3 & 5 & 3 & 4 & 4 & 4 & 5 & 4 & 3 & 5 & 3 & 4 & 4 & 72 \\
\hline USA & & & & & & & & & & & & & & & & & & \\
Total points = 5 & & & & & & & & & & & & & & & & & & & \\
Paula Creamer & 5 & 5 & 4 & 5 & 5 & 3 & 4 & 3 & 5 & 6 & 4 & 6 & 5 & $3^{f}$ & $4^{t}$ & $3^{f}$ & $3^{f}$ & $4^{t}$ & 77 \\
Stacy Lewis & 4 & 5 & 4 & 4 & 4 & 4 & 5 & 4 & 4 & 5 & 4 & 4 & 4 & 3 & 5 & 3 & 4 & 4 & 74 \\
Morgan Pressel & 5 & 5 & 4 & 4 & 4 & 3 & 5 & 3 & 4 & 4 & 3 & 4 & 4 & 3 & 6 & 3 & 4 & $3^{f}$ & 71 \\
Juli Inkster & 4 & 4 & 4 & 5 & 4 & 3 & 6 & 4 & 4 & 4 & 4 & 4 & 4 & 4 & 5 & 4 & 4 & 4 & 75 \\
Vicky Hurst & 4 & 4 & 4 & 5 & 5 & 4 & 5 & 2 & 4 & 4 & 4 & 5 & 4 & 3 & 4 & 3 & 4 & 3 & 71 \\
Brittany Lincicome & 5 & 4 & 4 & 5 & 4 & 3 & 4 & 2 & 4 & 5 & 4 & 5 & 4 & 3 & 5 & 3 & 4 & 4 & 72 \\
Brittany Lang & 4 & 5 & 3 & 4 & 4 & 3 & 5 & 3 & 4 & 4 & 5 & 4 & 4 & $3^{t}$ & $5^{t}$ & $3^{t}$ & $3^{t}$ & $4^{t}$ & 70 \\
Christina Kim & 4 & 5 & 4 & 3 & 4 & 2 & 5 & 3 & 4 & 3 & 4 & 5 & 5 & 3 & 6 & 2 & $4^{a}$ & $4^{f}$ & 70 \\
Michelle Wie & 5 & 4 & 5 & 4 & 4 & 4 & 4 & 3 & 3 & 4 & 5 & 4 & 5 & 3 & 4 & 3 & 3 & 4 & 71 \\
Ryann O'Toole & 4 & 5 & 4 & 5 & 6 & 3 & 4 & 4 & 3 & 4 & 4 & 4 & 4 & 4 & 5 & 3 & 5 & 5 & 76 \\
Angela Stanford & 4 & 6 & 4 & 4 & 5 & 4 & 4 & 3 & 4 & 4 & 4 & 6 & 4 & 3 & 5 & 3 & 4 & 3 & 74 \\
Cristie Kerr & $5^{f}$ & 5 & $5^{f}$ & $3^{s}$ & $3^{f}$ & $3^{t}$ & $4^{s}$ & $3^{s}$ & $5^{f}$ & $4^{f}$ & $4^{f}$ & $4^{s}$ & $4^{t}$ & $3^{s}$ & $5^{s}$ & $3^{f}$ & $4^{f}$ & $4^{s}$ & 70
\end{tabular}

$\mathbf{E U}$

Total points $=7$

Catriona Matthew $\quad \begin{array}{lllllllllllllllllllll}n^{t} & 5 & 4 & 3 & 4 & 5 & 3 & 3 & 3 & 5 & 5 & 4 & 5 & 5 & 3^{f} & 5^{t} & 3^{f} & 4^{t} & 4^{t} & 73\end{array}$

$\begin{array}{lllllllllllllllllllll}\text { Sophie Gustafson } & 5 & 5 & 4 & 4 & 4 & 3 & 4 & 5 & 4 & 4 & 4 & 4 & 4 & 3 & 5 & 3 & 4 & 3 & 72\end{array}$

$\begin{array}{lllllllllllllllllllll}\text { Anna Nordqvist } & 5 & 4 & 3 & 4 & 4 & 3 & 5 & 3 & 5 & 5 & 4 & 6 & 5 & 3 & 5 & 3 & 4 & 4^{a} & 75\end{array}$

$\begin{array}{lllllllllllllllllllll}\text { Laura Davies } & 5 & 6 & 4 & 5 & 4 & 3 & * 5 & 3 & 4 & 4 & 4 & 4 & 6 & 3 & 4 & 4 & 4 & 5 & 77\end{array}$

$\begin{array}{lllllllllllllllllllll}\text { Melissa Reid } & 4 & 7 & 4 & 5 & 5 & 3 & 5 & 3 & 5 & 4 & 4 & 4 & 4 & 3 & 4 & 3 & 4 & 4 & 75\end{array}$

$\begin{array}{lllllllllllllllllllll}\text { Christel Boeljon } & 5 & 4 & 3 & 5 & 3 & 3 & 4 & 3 & 4 & 4 & 5 & 5 & 4 & 3 & 5 & 3 & 4 & 3 & 70\end{array}$

$\begin{array}{lllllllllllllllllllllllll}\text { Sandra Gal } & 5 & 5 & 4 & 5 & 6 & 3 & 5 & 4 & 5 & 4 & 4 & 5 & 4 & 3^{f} & 4^{f} & 3^{a} & 4^{f} & 4^{f} & 77\end{array}$

$\begin{array}{lllllllllllllllllllll}\text { Maria Hjorth } & 4 & 6 & 4 & 5 & 5 & 3 & 4 & 3 & 4 & 4 & 5 & 4 & 5 & 3 & 5 & 4 & 5^{t} & 4^{a} & 77\end{array}$

$\begin{array}{lllllllllllllllllllll}\text { Suzann Pettersen } & 4 & 5 & 4 & 4 & 4 & 3 & 5 & 3 & 4 & 4 & 4 & 4 & 6 & 3 & 5 & 2 & 3 & 3 & 70\end{array}$

$\begin{array}{lllllllllllllllllllll}\text { Caroline Hedwal } & 4 & 6 & 5 & 4 & 4 & 3 & 4 & 4 & 4 & 4 & 5 & 4 & 4 & 4 & 5 & 3 & 4 & 3 & 74\end{array}$

$\begin{array}{lllllllllllllllllllll}\text { Azahara Munoz } & 5 & 6 & 4 & 3 & 5 & 3 & 4 & 3 & 4 & 5 & 4 & 5 & 4 & 5 & 5 & 3 & 3 & 3 & 74\end{array}$

\begin{tabular}{llllllllllllllllllll} 
Karen Stupples & $5^{t}$ & $5^{t}$ & $3^{t}$ & $5^{t}$ & $3^{t}$ & $3^{t}$ & $4^{t}$ & $3^{t}$ & $4^{t}$ & $4^{t}$ & $4^{t}$ & $6^{t}$ & $4^{t}$ & $3^{t}$ & $5^{t}$ & $3^{t}$ & $6^{t}$ & $6^{t}$ & 76 \\
\hline
\end{tabular}

Sunday Singles

$f=$ Friday Four-Ball

$s=$ Saturday Four-Ball

$t=$ Friday/Saturday Foursomes

$a=$ Assumed par

*Won by concession, lost by concession

Source: http: / /www. solheimcup. com.

for the occasion and beaten the odds. Finally, we simulated using 1000 replications with the hypothetical participation of Kerr. The expected outcome is 7.65 to 4.37 in favour of USA, with maxima of 9.5 and 6, and minima of 6 and 2.5 for USA and EU, respectively. The results give a relative measure of the higher odds against EU had Kerr been able to play. 


\section{The 2011 Presidents Cup}

As a first attempt of pre-game analysis to test the potential usefulness of our simulation models, we carried a real time experiment at the 2011 Presidents Cup which was held in Melbourne, Australia on 14-20 November, 2011. After the first three days of paired competitions, USA led International by a commanding lead of 4 points (13 to 9) and needed only 4 wins out of the 12 singles matches on Sunday to retain the Cup. Using the players' performance on the first three days as estimates, pre-game simulations were performed and the following posting was submitted to several public forums (see, e.g., Golfforum. com, 2011) as a matter of record:

Presidents Cup 2011 Posted 11-19-2011, 04:53 PM

Greetings! For fellow golf fans anticipating the finale of the Presidents Cup, with the 12 deciding singles matches to begin in just about 4 hours, here are some tidbits to help bide the time. Based on results of the first three days, our simulation models at the University of Illinois at Chicago project Team International to win the Sunday Singles 7 to 5, which let Team USA retain the cup with a total score of 18 to 16 . While the actual pairings come close to "expectation" (over all permutations) for both teams ( 6.89 for International and 5.18 for USA), there are optimal combinations which give 8.5 to International (just enough to win the cup), and 7.5 to USA, respectively. In any case, our results predict that the final day matches should still be exciting to watch, despite the seemingly commanding lead of 4 points by Team USA (13 to 9).

Jim Ho

UIC

Indeed, it turned out to be an exciting final day of singles competition with the teams splitting the matches 6 to 6 , and the final results of USA 19 to International 15

\section{Conclusion}

We have presented spreadsheet simulation models for the analysis of pairing strategies for both singles and doubles match-play for team competition in golf tournaments. While totally random pairings and expected outcomes are deployed in the convention of well grounded statistical methodology, the recommendation is to use the approach as a decision support tool, in conjunction with insight, acumen, and leadership typically expected in captains and coaches. In particular, the models should be most useful when variations of a theme are to be analysed. For example, a captain may for a variety of reasons have decided on the major structure of the pairings. However, there are subtle variations and switches that he or she may wish to explore. The simulation models can then be applied to provide further insight and inspiration for competitive and strategic decisions. We plan to experiment with the approach at various levels of competition and report on the findings in the future. 


\section{References}

Clark, J. (2010). Back on track? The outlook for the global sports market to 2013. PricewaterhouseCoopers LLP Hospitality and Leisure Sector Report, May 2010.

Dorsel, T.N., Rotunda, R.J. (2001). Low scores, top 10 finishes, and big money: an analysis of Professional Golf Association tour statistics and how these relate to overall performance. Perceptual and Motor Skills, $92,575-585$.

Fried, H., Lambrinos, J., Tynerb, J. (2004). Evaluating the performance of professional golfers on the PGA, LPGA and SPGA tours. European Journal of Operational Research, 154(2), 548-561.

Golf Forum (2001). http: / /www. golfforum. com/introductions-greets /18449presidents-cup-2011-a.html. Accessed 19 November, 2011.

Guryan, J., Kroft, K., Notowidigdo, M. (2009). Peer effects in the workplace: evidence from random groupings in professional golf tournaments. American Economic Journal: Applied Economics, 1(4), 34-68.

Ketzscher, R., Ringrose, T. (2002). Exploratory analysis of European Professional Golf Association statistics. The Statistician, 51(2), 215-228.

McHale, I., Forrest, D. (2005). The importance of recent scores in a forecasting model for professional golf tournaments. IMA Journal of Management Mathematics, 6(2), 131-140.

Moscato, D.R., Moscato, E.D. (2004). A taxonomy of a decision support system for professional sports. Issues in Information Systems, 5(2), 633-639.

Nicklaus, J. (2004). Golf Digest, September issue.

PGA Tour (2007). The 2007 Presidents Cup at the Royal Montreal Golf Club, Montreal, Canada. http://www.pgatour.com/tournaments/presidentscup/scoring/2007/. Accessed 30 September, 2007.

Ragsdale, C.T., Scheibe, K.P., Trick, M.A. (2008). Fashioning fair foursomes for the fairways (using a spreadsheet-based DSS as the driver). Decision Support Systems, 45(4), 997-1006.

Şeref, M., Ahuja, R., Winston, W. (2007). Developing Spreadsheet-Based Decision Support Systems Using Excel and VBA for Excel. Dynamic Ideas, Belmont.

Solheim Cup (2011). Killeen Castle, County Meath, Ireland. 23-25 September, 2011. http: / / www. solheimcup. com/. Accessed 30 September, 2011.

Wright, M.B. (2009) 'Fifty years of operational research in sports', Journal of the Operational Research Society, 60(1), S161-S168.

J.K. Ho is a professor of information and decision sciences at the University of Illinois at Chicago. His recent work focuses on simulation modelling of competitive strategies for project and operations management, and maximum resolution dichotomies for data mining and visualisation.

\section{Imitaciniai sprendimụ paramos skaičiuoklès modeliai: strateginio poravimo komandinèse varžybose atvejis}

\section{James K. HO}

Komandinèse sporto varžybose žaideju poravimas turi esminę reikšmę. Šis straipsnis pateikia imitacinius modelius, naudojančius vien tik standartinę skaičiuokliu programinę įrangą, tikslu analizuoti ir lyginti poravimo strategijas, pagrịstas numatoma arba faktine individualiu žaidèjų veikla. Tai gali būti naudinga kapitonams ir treneriams universitetų, klubų, lygų bei tarptautinèse sporto varžybose. 